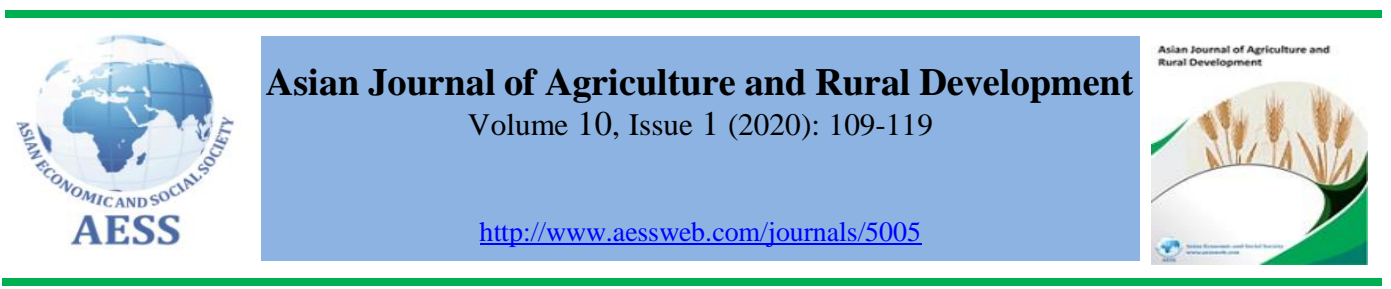

\title{
AN ASSESSMENT OF THE USE OF AGRICULTURAL MARKETING EXTENSION AMONG EXTENSION METHODS: INSIGHT FROM JORDAN
}

Radi Altarawneh $^{\mathrm{a}}$, ${ }^{\mathrm{a}}$ Department of Agricultural Economics and Extension, Faculty of

Ali Al-Sharafat a, Agriculture, Jerash University, Jordan

Mohammad

Altarawneh ${ }^{\text {a }}$

$\bowtie$ m.tarawneh@jpu.edu.jo (Corresponding author)

\section{ARTICLE HISTORY:}

Received: 20-Dec-2019

Accepted: 02-Mar-2020

Online Available: 24-Mar2020

\section{Keywords:}

Agricultural extension, Public extension agents, Marketing extension, Jordan

\section{ABSTRACT}

This study aimed at assessing the use of agricultural marketing extension services among extension methods provided by public agricultural extension agents in Jordan. A sample survey of public agricultural extension agents was conducted covering the whole Agricultural Directorates in the country. The survey employed a structured questionnaire with pre-coded questions. The entire sample consists of 107 agricultural extension agents. To achieve its goals qualitative as well as quantitative analytical procedures were adopted in this study. A Four point likert-scales was used to compute the respondents overall mean score. The study provided empirical evidence about the lack of agricultural marketing extension among extension methods used by public extension agents in Jordan. Public extension agents in Jordan consider agricultural marketing extension with low priority during their extensive activity. Public agricultural extension activities should be directed to enhance marketing extension activities. Extension methods such as newspapers, radio, TV, mobile, internet and experts systems should be strongly considered to spread marketing knowledge to the farmers. Public agricultural extension activities should be directed to enhance marketing extension activities. Extension methods such as newspapers, radio, TV, mobile, internet and experts systems should be strongly considered to spread marketing knowledge to the farmers.

\section{Contribution/ Originality}

In Jordan perspective, it is the first contribution to the literature regarding marketing extension. So, it provides a pioneer model for extension agents who may be less familiar with marketing extension activities. The results of the paper characterize all possible issues providing in the long term a basis for devising useful and helpful extension structures beyond what is addressed in the paper.

DOI: 10.18488/journal.1005/2020.10.1/1005.1.109.119

ISSN (P): 2304-1455/ISSN (E):2224-4433

How to cite: Radi Altarawneh, Ali Al-Sharafat and Mohammad Altarawneh (2020). An Assessment of the use of Agricultural Marketing Extension among Extension Methods: Insight from Jordan. Asian Journal of Agriculture and Rural Development, 10(1), 109-119.

(C) 2020 Asian Economic and Social Society. All rights reserved. 


\section{INTRODUCTION}

In agricultural activities, adopting new technologies is crucial in raising productivity (Morris, 2007). Lack of information provided to farmers will result in low adoption rates of new technologies needed for better production practices which will end in achieving poor outcomes (Anderson and Feder, 2003). One of the most considered tools in delivering knowledge and skills to improve farmers capacity in adopting new technologies related to advanced agricultural production is agricultural extension service (Anderson and Feder, 2004). Development and dissemination of new agricultural production technologies are the only mechanism to achieve agricultural productivity growth (Asfaw et al., 2012). Providing information for farmers and educating them about applying new technologies is the main goal of the agricultural extension services providers (Rivera et al., 2006; Anderson and Feder, 2004). FAO (2010) defined agricultural extension as; "systems that should facilitate the access of farmers, their organizations and other market actors to knowledge, information and technologies; facilitate their interaction with partners in research, education, agribusiness, and other relevant institutions; and assist them to develop their own technical, organizational and management skills and practices". Various studies revealed that agricultural extension services contributed to increased productivity and farm income (Huffman, 1976; Owens et al., 2003). Lee et al., (2017) stated that extension increases not only farmers' direct output, but also allocative ability in crop production. Improved productivity is one of the most important contributions of agricultural extension activities (Birkhaeuser et al., 1991). Anderson and Feder (2004) argued that agricultural extension is one of the most important systems to reduce the productivity differential. Onwuka et al. (2017) concluded that extension services have increased farmers' productivity, income and also improved their welfare. Swanson (2008) also argued that the extension service goes beyond technology transfer to general community development.

Among many agricultural extension services the concept and practice of marketing extension have not yet deeply rooted in the public extension service (Shepherd, 2007). Of one of its well-known reports, Oxfam America (2011) reported that; "there is critical knowledge and skills gaps in market oriented extension and communication skills". The report confirmed the need for a certain level of competencies and skills of public agricultural extension agents to provide market oriented extension services farmers. A well-developed public agricultural extension system is critical to have access to proper knowledge about markets (UNDP, 2012).

It is very important to investigate the effects of public marketing extension services as well as to analyze if these services raise agricultural output and assist farmers to make more revenue and profit. A study conducted by Alhabbab and Alrimai (2002) showed that $73 \%$ of the agricultural producers in Jordan indicated their need for marketing guidance. This study is an attempt to assess the use of public agricultural marketing extension among extension methods in Jordan.

\section{THE AGRICULTURAL SECTOR IN JORDAN}

In Jordan, according to the Jordanian Ministry of Agriculture (MoA), the agricultural sector is one of the most important sectors contributing to country's economy. Its importance is not only limited to creating farming jobs. It contributes to the Kingdom's exports and GDP (MoA, 2017). Despite its noticed importance for the country, due to the scarcity of water, agriculture has been declining as a component of the overall economy for years. It consumes around $70 \%$ of Jordan's water resources. According to ESCWA (2016) the agriculture and food sector contributes to the livelihood of about a quarter of the active population in Jordan. The Jordanian Ministry of Agriculture (MoA) agricultural statistical records showed that the value of the Agricultural Gross Domestic Product (AGDP) reached 1137 million USD at current prices in the year 2018 constituting about 3.8\% of the country's Gross Domestic Product (GDP). The AGDP growth rate 
for the current decade exceeded $18 \%$. Approximately $60 \%$ of the agricultural production in Jordan is used as intermediate goods for other sectors. The total added value in the national economy resulting from the cross-linking of the agricultural sector with other sectors is estimated at 3.76 billion USD, representing $16 \%$ of the country's GDP. The value of agricultural exports exceeded 0.7 billion USD constituting about $20 \%$ of the total exports value of the country (MoA, 2018). Figures 1, 2 and 3 show development of areas (in $\mathrm{m}^{2}$ ) of each of the three main components of the agricultural sector in Jordan from 2013 - 2017, while figures 4, 5 and 6 show development of the main livestock components for the period 2008 - 2017.

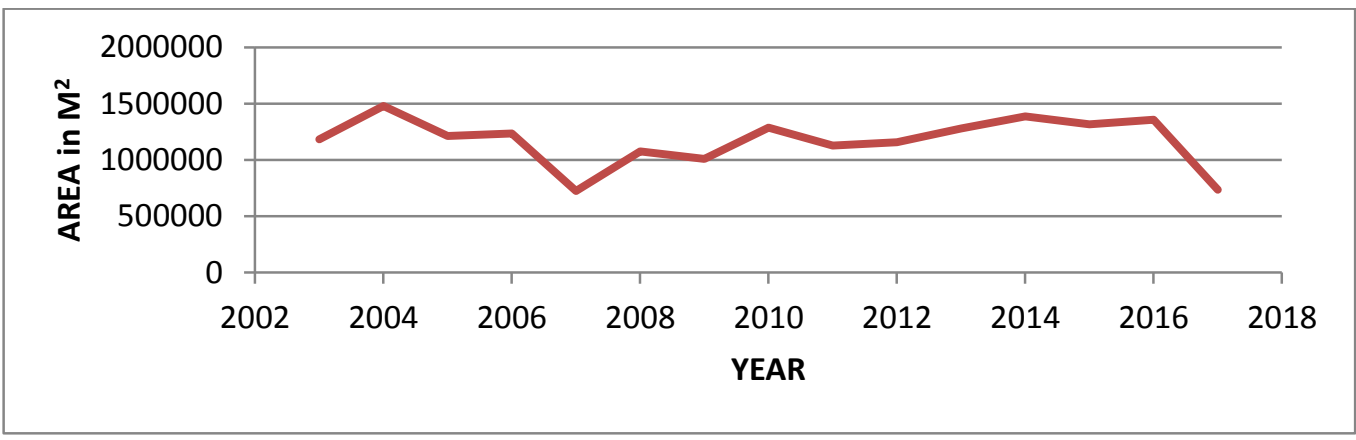

Figure 1: Development of Field Crops areas in Jordan (2003-2017)

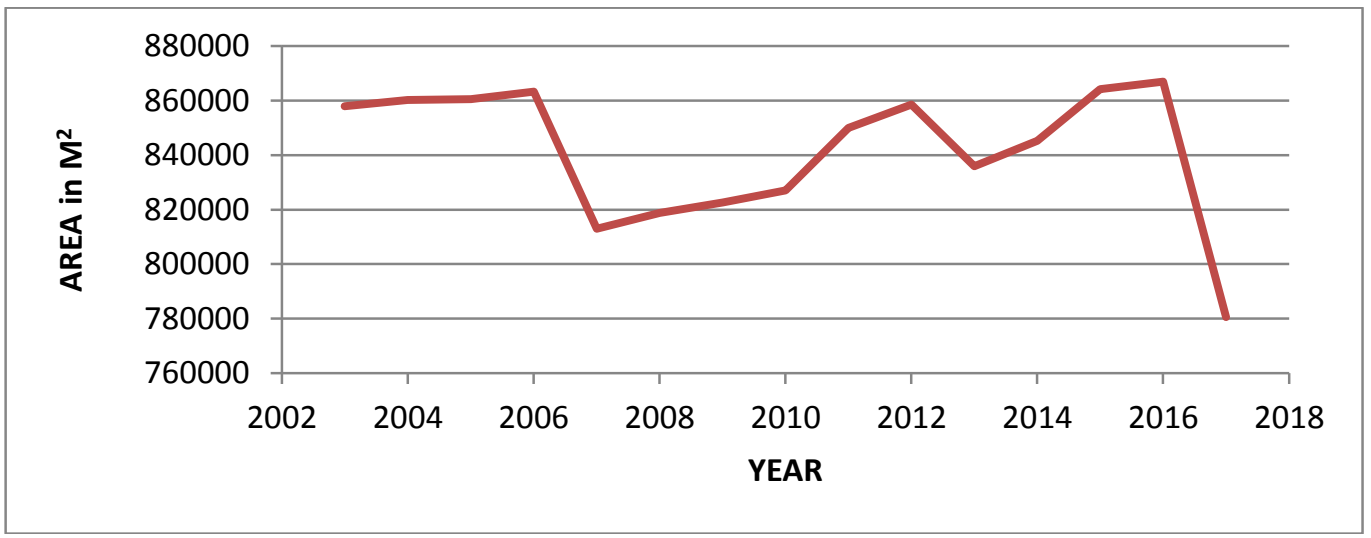

Figure 2: Development of fruit trees areas in Jordan (2003-2017)

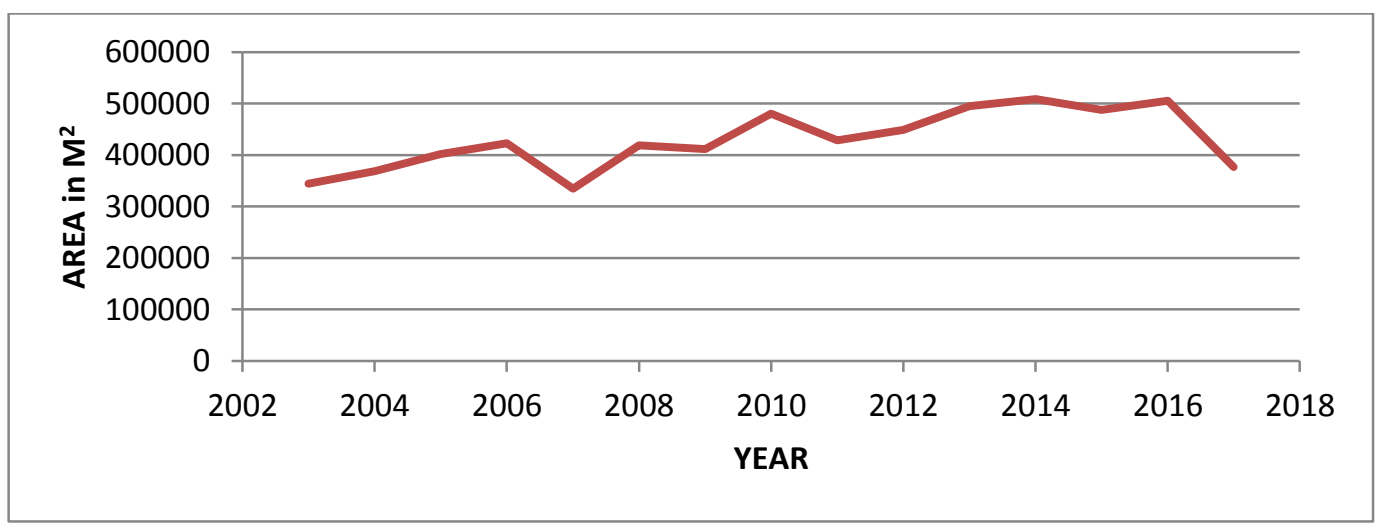

Figure 3: Development of Vegetables areas in Jordan (2003-2017) 


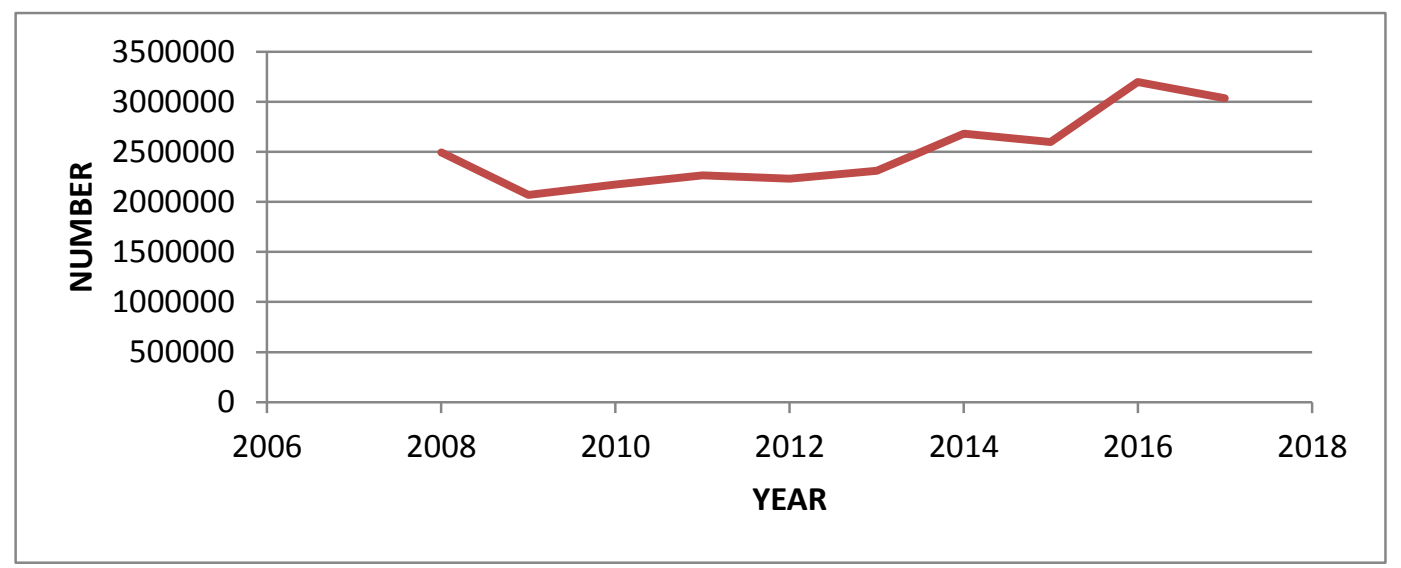

Figure 4: Development of Sheep Number in Jordan (2008-2017)

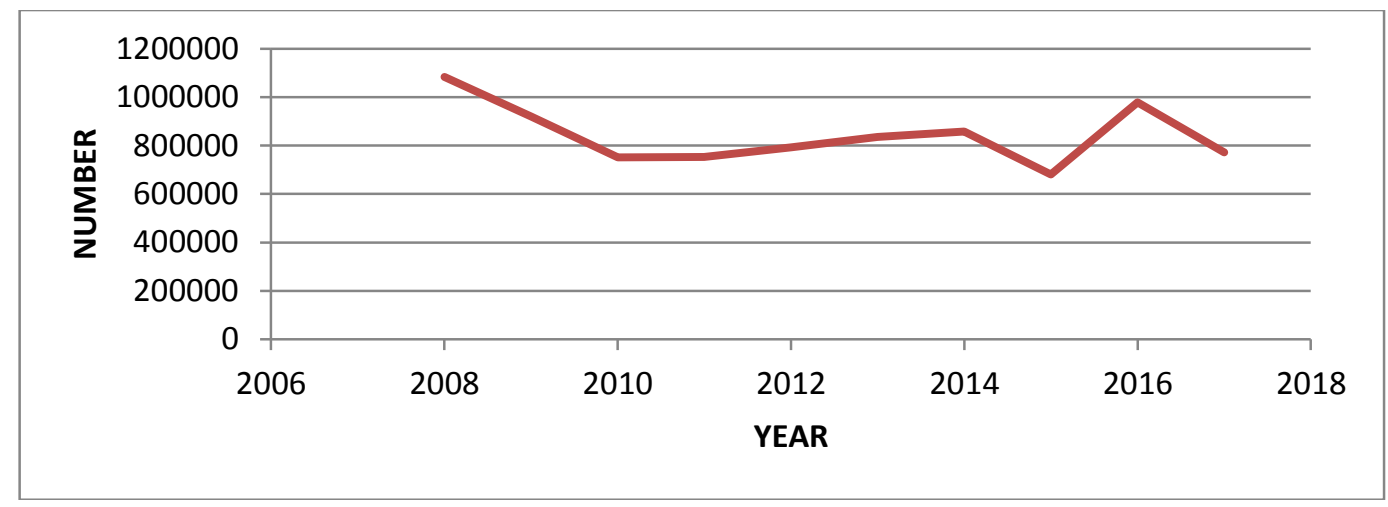

Figure 5: Development of Goats Number in Jordan (2008-2017)

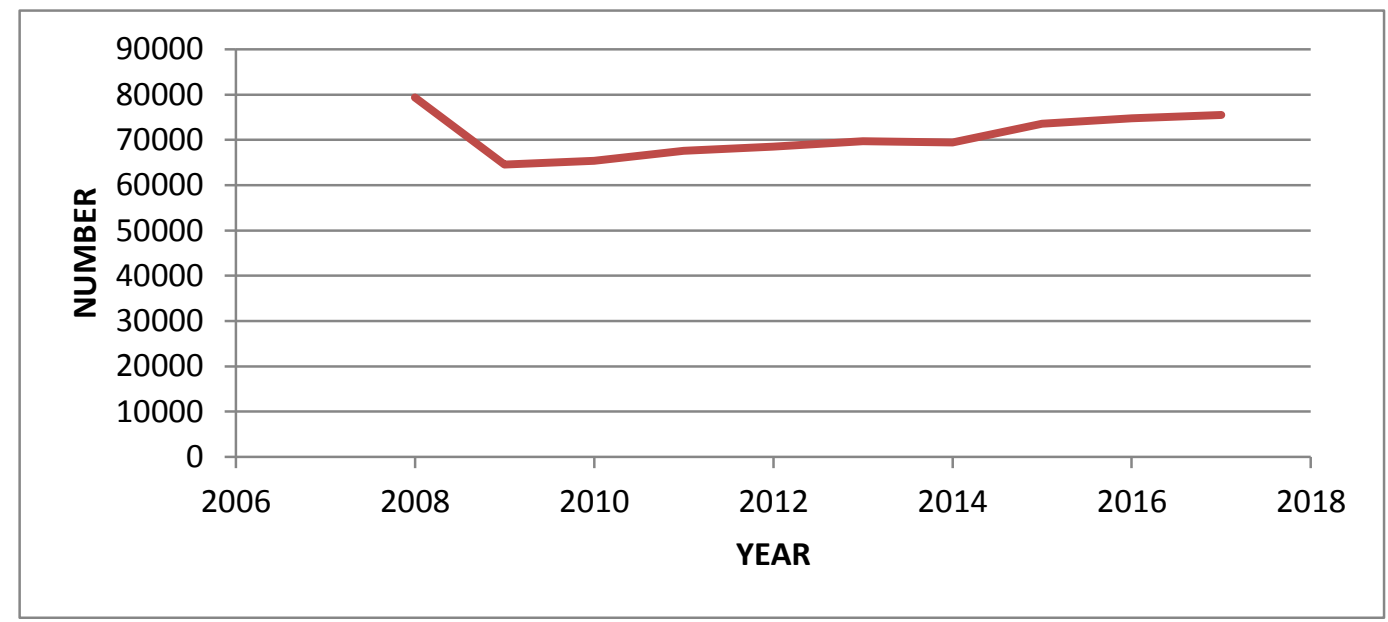

Figure 6: Development of Cattle Number in Jordan (2008-2017)

As showed in the figures above, the largest areas were cultivated field crops followed by fruit trees and then vegetables. Decline in the areas cultivated with two of the three components is noticed. The areas cultivated with field crops declined from 1184.23 million $\mathrm{m} 2$ in 2003 to 736.73 million 
$\mathrm{m} 2$ in 2017. The areas cultivated with fruit trees declined from 857.91 million $\mathrm{m} 2$ in 2003 to 780.63 million $\mathrm{m} 2$ in 2017. The areas cultivated with vegetables increased from 344.23 million $\mathrm{m} 2$ in 2003 to $344.23 \mathrm{~m} 2$ in 2017 (MoA, 2017). The decline in field crops, fruit trees areas, cattle and goat numbers could be attributed mainly to water scarcity problem in Jordan. Climate change consequences which largely impacted the agricultural sector also resulted in diminishing farmers' incomes. Agricultural products price fluctuations as well as the increase in farm business input accompanied by agricultural products poor marketing system is another main reason for many farmers to leave agricultural business in both plant and animal production sectors.

The agricultural sector in Jordan faces a set of obstacles and challenges that affect the development efforts undertaken by the government to develop this sector, the most important of which are (MoA, 2018):

1. Limited available agricultural resources, such as land resources, the scarcity and low quality of water resources, and the dependence of Jordanian agriculture in most of it on rainwater.

2. Weak agricultural development policies during the past three decades.

3. Evaluating the agricultural sector from the perspective of its direct contribution to the gross domestic product, and neglecting the main role of the sector in economic, social and rural development.

4. High indebtedness of the agricultural sector, represented by the indebtedness of the farmers, which led to the weak ability of farmers to adopt modern production techniques that increase the efficiency of agricultural production and use resources properly.

5. Weak government agricultural guidance and the lack of financial and human resources allocated to it in several agricultural fields, especially with regard to adopting modern agricultural techniques and methods.

6. Decline in marketing outlets for Jordanian products to neighboring countries as a result of factors related to the conditions in these countries, such as Syria and Iraq.

7. Continuing deterioration of the vegetation covers of the natural pasture land and the decline of their productive capacities.

\section{PUBLIC AGRICULTURAL EXTENSION IN JORDAN}

In Jordan, the public extension service body is the most popular regarding providing agricultural extension services. Providing agricultural extension services was one of the most important functions of the Jordanian MoA when established in 1939. Despite of this, institutionalization of the extension services was realized in 1954 by creating a division of agricultural Extension followed by establishment of the Department of Rural in 1961, which was named the Department of Agricultural Extension in 1962, which in turn merged with the Department of Scientific Research in 1970 and renamed the Department of Agricultural Research and Extension. This merger sought to enhance cooperation between researchers and extension agents. In 1986 the National Center for Research and Transfer of Technology (NCARTT) was established to replace the Department of Agricultural Research and Extension. The NCARTT consisted of five divisions; one of them was the Department of Agricultural Extension which was separated in 1992 to a new body named the Department of Agricultural Extension and Information. The main duties of these bodies were providing advisory services to farmers in order to promote agricultural production, to achieve agricultural policy objectives, and to disseminate information among farmers in order to change their attitudes and to be more receptive to new agricultural technologies (Al-Rimawi and Arabiat, 1997).

In 2008 a merger was undertaken between research and extension function, where the National Center for Agricultural Research and Extension was created, NCARTT was reformed to resume 
responsibility for extension and its name was changed to National Center for Agricultural Research and Extension (Boubaker et al., 2017).

In 2018 the Public Agricultural Extension activities in the country were the responsibility of the $\mathrm{MoA}$ as a separate sector, and the directorates of Extension Programs, Training and Educating Farmers and Documenting Farm Holdings and Records was affiliated with it. The Marketing Extension Programs Section was affiliated with the Directorate of Extension Programs (MoA, 2018). Table 1 shows number of those agents according to their specialization.

Table 1: Number of public agricultural extension agents in Jordan (2018)

\begin{tabular}{lc}
\hline Specialization & Number \\
\hline Plant Production & 47 \\
Plant Protection & 16 \\
Agricultural Economics and Extension & 15 \\
Soil and Irrigation & 8 \\
Animal Production and Protection & 18 \\
Nutrition and Food Processing & 4 \\
Orchards & 2 \\
Forestry & 3 \\
Farm Management & 3 \\
Veterinary medicine & 1 \\
Total & 117 \\
\hline
\end{tabular}

Source: MoA (2018)

Public extension services in Jordan have been criticized for low coverage of farmers, including the small number of extension workers, their unsatisfactory technical know-how, as well as their lack of proper program planning and evaluation. Some of the factors responsible for unsatisfactory services are the small number of extension workers, their insufficient operational funding, their lack of transportation facilities and rare in-service training (MoA, 2018).

\section{AGRICULTURAL MARKETING EXTENSION}

Mwada et al. (2019) reported that: "the concept of agricultural marketing extension may be new, however it could be regarded as the most neglected part of extension activities". In trying to show the importance of this type of extension, they also reported: "agricultural marketing extension is concerned with making the farmer understand and take advantage of market opportunities". Agricultural marketing extension can be described as; "an education program which provides information to farmers to solve marketing problems" (Çukur, 2013). Mungroo and Seppersad (1995) confirmed that agricultural marketing extension covers; "all marketing activities from production to the retail level and can be effective in putting the farmers in touch with the reality of the market. Mungroo and Seppersad (1995) also concluded that; "agricultural marketing extension can effectively put farmers in touch with the realities of the market place and increase the efficiency with which they market their produce". Main activities to be covered by agricultural marketing extension range from production decision to consumer response to products. These activities include teaching the farmers how to use all the information that is available in deciding what crops to produce. They must learn to determine what the market wants before deciding what to produce. The agricultural extension activities also include teaching the farmers how to employ proper harvesting and post-harvesting practices to produce a product with desired form and quality. Also, the activities teach the farmers how to access and interpret marketing and price information (Mungroo and Seppersad, 1995). Berhanu et al. (2015) summarized functions of market-oriented extension as a means for achieving improved and sustainable livelihoods for the rural population 
and as total effort of extension service to support farmers to produce profitable products, to collect market information, to identify profitable markets and to build marketing capacity of producers. They also presented the key principles of market-oriented extension as business principles related to income and resource principles related to the comparative advantages of a given area. The primary focus of agricultural extension today is on enhancing incomes through market-orientation (Christoplos, 2010). Market-oriented agricultural advisory services help farmers to overcome constraints related to a lack of adequate know-how and skills (Mwada et al., 2019).

In conducting their agricultural activities farmers, as key players, are faced with many challenges related to market their products, therefore, they need the support of agricultural marketing extension agents. Figure 7 shows the value chain approach to market-oriented advisory extension services. A value chain is a set of connected activities that work together in order to add value to a product, while linking buyers, sellers and markets (GFRAS, 2016).

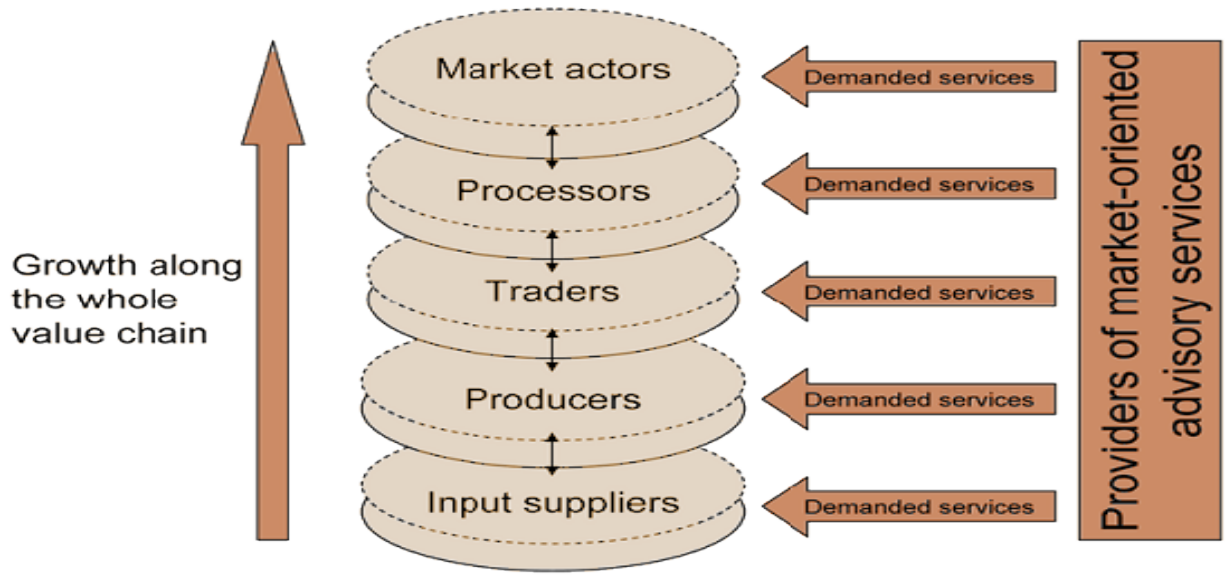

Figure 7: Value chain approach to market-oriented advisory extension services

Source: Neuchatel Group (2008)

In Jordan, as mentioned earlier, the Marketing Extension Programs Section was affiliated with the Directorate of Extension Programs. According to the MoA website, this section is responsible for:

1. Preparing specialized extension programs to guide agricultural systems to improve product quality.

2. Directing and guiding farmers to adopt high-value crops that contribute to reducing marketing bottlenecks.

3. Preparing guidance programs to increase the added value of plant and animal products.

4. Preparing annual programs for exhibitions and festivals to promote agricultural and rural products.

5. Guiding farmers to adopt pre- and post-harvest techniques and encourage contract farming.

6. Preparing training programs to build the capacity of extension workers and target groups in agricultural marketing issues.

7. Preparing marketing plans and periodic achievements reports.

\section{MATERIALS AND METHODS}

\subsection{Sample, data collection and study hypothesis}

Data was obtained mainly from primary sources through the use of a structured questionnaire. Purpose simple random sampling was used to select the respondents. A sample survey of public 
agricultural extension agents was conducted covering the whole Agricultural Directorates in the country. The survey employed a structured questionnaire with pre-coded questions. The entire sample consists of 107 agricultural extension agents. The researchers explained details of this study and gave agents enough information about the reason for the study before conducting the survey. Results are based on descriptive analysis of the survey data.

In order to predict that the agricultural marketing extension is adopted within public extension methods used by public agricultural extension agents in Jordan, the study will try to test the following statement:

$\mathrm{H}_{0}$ : Agricultural marketing extension is adopted within public extension in Jordan.

The alternative statement is:

$\mathrm{H}_{1}$ : Agricultural marketing extension is not adopted within public extension in Jordan.

\subsection{Analytical techniques}

Qualitative as well as quantitative analytical procedures were adopted in this study. Descriptive statistical tools such as measures of central tendency such as means, percentages, standard deviation and frequency distributions were used to achieve objectives of the study. Four point likert-scale was used to compute the respondents overall mean score. The extension methods were itemized and the respondents were asked to indicate the degree they use the agricultural marketing extension approach in each method. The 13 extension methods were used to assess the use of agricultural marketing extension that include, home visits, field visits, extension meetings, extension fields, field days, farmers field schools, extension publications, newspapers, radio, television, telephone/mobile, internet, and expert systems.

The scale had been ranked as follows: Always as 4 points, Sometimes as 3 points, Rarely as 2 point, and Never as 1 point. The weighted mean score was obtained by dividing the total weighted score for all the options by the number of respondents to obtain a mean sore for each statement. The Likert formula is:

Where;

$$
X_{s}=\sum F_{n} / N_{r}
$$

$\mathrm{Xs}=$ Mean score,

$\sum=$ summation,

$\mathrm{F}=$ frequency of each $(4,3,2,1)$ option,

$\mathrm{n}=$ responses of the respondents,

$\mathrm{Nr}=$ total number of respondents.

The judgment value was 2.5 , which was obtained by dividing the total score value by the number of the options $(4+3+2+1 / 4)$. This is also applicable to compatibility and complexity. That is, any method with a mean score equal to or above 2.5 means that the agricultural marketing extension approach is adopted within the extension method and so we accept the method as an agricultural marketing extension one, and any statement with a mean score less than 2.5 means that the agricultural marketing extension approach is not adopted within this method and the method is rejected as an agricultural marketing extension one. The data were analyzed with Statistical Package for Social Sciences (SPSS).

\section{RESULTS AND DISCUSSION}

\subsection{Agricultural marketing extension}

The results of the study revealed that all of the respondents were aware of the concepts related to agricultural marketing extension. This result may be explained by the fact that all of the 
interviewed extension agents were bachelor degree holders in several agricultural disciplines. Agricultural extension including agricultural marketing extension topics was covered by several courses during their college study. The results also showed that almost $80 \%$ of the respondents considered agricultural marketing extension with low priority during their extension activity. About $19 \%$ of them considered this type of extension with moderate priority and nearly $1 \%$ considered it with no priority at all. No one of the agents is considered the agricultural marketing extension with high priority compared to other types of extension activities. This result indicates that although the extension agents are aware of marketing extension activities are not concentrating on this type of extension when performing their job. This situation reflected negatively on the performance of the farmers when dealing with marketing issues. Another related result of this study indicated that only $21 \%$ of the respondents used agricultural marketing extension as a separate professional program while $79 \%$ of the respondents, with little attention, used it within other extension programs. This result proves that agricultural marketing extension is not a major one among other extension activities and not receiving enough attention. The results of the study also indicated that $55 \%$ of the agricultural marketing extension activities were directed mainly to top farmers and investors, while only $9 \%$ of these activities are directed to small farmers. This means that agricultural marketing extension is in fact directed to farmers who do not need this type of extension and neglecting those who need it. Results related to market problems facing farmers showed that the main problems include lack of markets and high exporting costs. The results also indicated that lack of agricultural marketing extension professionals and lack of capital are the main problems which are needed to be solved to guarantee effective agricultural marketing extension.

\subsection{Adopting agricultural marketing extension}

The results of statistical analysis regarding the use of agricultural marketing extension among public extension methods are presented in Table 2. The table shows mean score and standard deviations of respondents' answers according related to the use of marketing extension.

Table 2: Mean scores and standard deviations of respondents' answers

\begin{tabular}{lcc}
\hline Method & Mean Score & Standard Deviation \\
\hline Home visits & 2.7 & 0.506 \\
Field visits & 2.9 & 0.167 \\
Extension meetings & 3.0 & 0.339 \\
Extension fields & 3.1 & 0.422 \\
Field days & 2.9 & 0.518 \\
Farmers field schools & 3.3 & 0.620 \\
Extension publications & 2.7 & 0.950 \\
Newspapers & 1.9 & 0.494 \\
Radio & 1.8 & 0.555 \\
Television & 1.8 & 0.516 \\
Mobile, ... & 1.8 & 0.568 \\
Internet & 1.6 & 0.545 \\
Expert systems & 1.6 & 0.596 \\
Average (Overall result) & 2.38 & 0.287 \\
\hline
\end{tabular}

Source: Authors own analysis

Results, as presented in Table 2 reveal that the overall mean score is 2.38 , which is less than judgment value of 2.5 presented in section 5.2. According to the decision rule that serve to judge that agricultural marketing extension is adopted within public extension or not, the overall mean score value indicates that we can't accept the null-hypothesis which states that agricultural marketing extension is adopted among public extension in Jordan. 


\section{CONCLUSIONS AND RECOMMENDATIONS}

The results of this study showed that public extension agents consider agricultural marketing extension with low priority during their extension activity. Although all of the respondents interviewed in this study were aware of the concepts related to agricultural marketing extension, empirical evidence was provided in this study about the lack of agricultural marketing extension among extension methods used by public extension agents in Jordan. The results of the study revealed that the overall mean score to test if marketing extension activities are included within public extension activities in Jordan was lower than the determined judgment statistical value, indicating lack of marketing extension activities in Jordan. Public agricultural extension activities should be directed to enhance marketing extension activities. Extension methods such as newspapers, radio, TV, mobile, internet and experts systems should be strongly considered to spread marketing knowledge to the farmers.

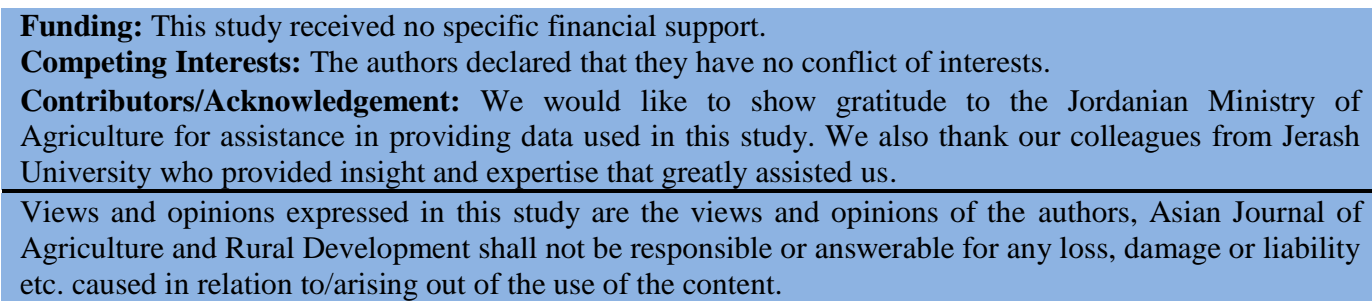

\section{References}

Alhabbab S., \& Al-Rimawi A. (2002). The appraisal of the agricultural marketing extension services for horticultural crops in the Jordan Valley. Dirasat, 29(3), 167-181.

Al-Rimawi, A. S., \& Arabiat S. (1997). Agricultural extension in Jordan; a critical review conference: rural knowledge systems for the 21st Century. A Symposium held on 17 July, 1997 at Reading: Cambridge and Edinburgh, Reading University, United Kingdom.

Anderson, J. R., \& Feder, G. (2004). Agricultural extension: Good intentions and hard realities. The World Bank Research Observer, 19(1), 41-60. doi.org/10.1093/wbro/lkh013.

Anderson, J. R., \& Feder, G. (2003). Rural extension services. World Bank Policy Research Working Paper 2976. Washington, DC: World Bank.

Asfaw, S., Shiferaw, B., Simtowe, F., \& Lipper, L. (2012). Impact of modern agricultural technologies on smallholder welfare: evidence from Tanzania and Ethiopia. Food Policy: 37(3), 283-295.

Berhanu, G., Dirk, H., \& Azage, T. (2015). Market-oriented extension service for agricultural transformation in Ethiopia. ILRI-LIVES Project Seminar on 6 May, 2015 at Ministry of Agriculture, Addis Ababa, Ethiopia.

Birkhaeuser, D., Evenson, R. E., \& Feder, G. (1991). The economic impact of agricultural extension: A review. Economic Development and Cultural Change, 39(3), 607-650. doi.org/10.1086/451893.

Boubaker, D., Kassam, S. N., Aw-Hassan, A., \& Al Rusheidat, J. (2017). Enhancing agricultural extension services for rural development in Jordan. International Journal of Agricultural Extension, 5(2), 51-60.

Christoplos, I. (2010). Mobilizing the potential of rural and agricultural extension FAO. Office of Knowledge Exchange, Research and Extension: The Global Forum for Rural Advisory Services, Viale delle Terme di Caracalla, 00153 Rome, Italy.

Çukur, T., Karaturhan, B., \& Budak, D. B. (2013). The importance of agricultural marketing extension. Ege Üniversitesi Ziraat Fakültesi Dergisi, No. Special Issue Volume 1, 265-269.

Economic and Social Commission for Western Asia (ESCWA) (2016). Survey of Economic and Social Developments in the Arab Region. 
Food and Agriculture Organization (FAO) (2010). Of the United Nations. Ethiopia Country Brief. Retrieved from www.fao.org/countries/55528/en/eth/.

Global Forum for Rural Advisory Services (GFRAS). (2016). Module 10: the role of extension in supporting value chains part 1, Theory Module 10: The Role of Extension in Supporting Value Chains Part 1, Theory. GFRAS_NELK_M10_Value_Chains-Manual-Part1.pdf.

Huffman, W. E. (1976). The value of the productive time of farm wives: Iowa, North Carolina, and Oklahoma. American Journal of Agricultural Economics, 58(5), 836-841.

Lee, Y., An, D., \& Kim, T. (2017). The effects of agricultural extension service on farm productivity: evidence from Mbale district in Uganda. Preprint, 1(04), 1-11. doi: 10.20944/preprints201704.0162.v1.

MoA - Ministry of Agriculture (2017). Statistical Book. Amman-Jordan.

MoA - Ministry of Agriculture (2018). Statistical Book. Amman-Jordan.

Morris, M. L. (2007). Fertilizer use in African agriculture: Lessons learned and good practice guidelines. World Bank Publications. WP No 6650. The World Bank. USA.

Mungroo, N., \& Seppersad, J. (1995). Extension services for agricultural marketing. $31^{\text {st }}$ Annual Meeting, July 10-14, 1995, Dover, Barbados 257096, Caribbean Food Crops Society. DOI: 10.22004/ag.econ.257096.

Mwada, M., Alhaji, A., \& Rahila, C. (2019). Review on market re-orientation of extension services for value chain development in Borno State, Nigeria. Journal of Agricultural Extension and Rural Development. 11(10), 162-168 DOI: 10.5897/JAERD2019.1073.

Neuchatel Group. (2008). Common framework on market-oriented agricultural advisory services. Forthcoming publication of the Neuchatel Group being printed by the Swiss Centre for Agricultural Extension and Rural Development (AGRIDEA), Lindau, Switzerland. Neuchatel Group, Switzerland 7-37.

Onwuka, F., Ndidiamaka, O., Justina, N., \& Okonkwo, C. J. (2017). Effectiveness of extension services in enhancing the productivity, income and welfare of women farmers cooperatives in Kajuru local government area of Kaduna State. IIARD International Journal of Economics and Business Management, 3 No. 8; 86-100.

Owens, T., Hoddinott, J., \& Kinsey, B. (2003). The impact of agricultural extension on farm production in resettlement areas of Zimbabwe. Economic Development and Cultural Change, 51(2), 337-357. doi.org/10.1086/346113.

Oxfam America-Horn of Africa Regional Office. (2011). Report on development agents' capacity building needs assessment. Strengthening the Ethiopian agricultural extension system project. Addis Ababa.

Rivera, W. M., Alex, G., Hanson, J., \& Birner, R. (2006). Enabling agriculture: The evolution and promise of agricultural knowledge framework. Proceedings of the $22^{\text {nd }}$ Annual Conference of the association for international agricultural and extension education, Clearwater Beach Florida, USA, 580-591.

Shepherd, A. W. (2007). Approaches to linking producers to markets: A review of experiences to date. Agricultural Management, Marketing and Finance Occasional Paper 13. Rome: Food and Agriculture Organization of the United Nations.

Swanson, B. E. (2008). Global review of good agricultural extension and advisory service practices. Rome: Food and Agriculture Organization of the United Nations.

United Nations Development Program (UNDP). (2012). Promoting ICT based agricultural knowledge management to increase production and productivity of smallholder farmers in Ethiopia. Development Brief No. 3. 